„Logopedia Silesiana”, t. 7, ISSN 2391-4297

DOI 10.31261/LOGOPEDIASILESIANA.2018.08.20

(cc) BY-SA

\author{
Aneta Syta \\ Department of Speech Therapy and Voice Emission, \\ University of Warsaw \\ (D) 0000-0001-7487-4083
}

\title{
Selected Cognitive Techniques of Neurological Music Therapy in Acoustic-Amnesic Aphasia Therapy Case Study
}

\begin{abstract}
Aвstract: Music is able to stimulate the human brain at different levels, resulting in greater durability of treatment results, as well as the overall health of patients is improved. The aim of the article is to present the use of cognitive neurological music therapy techniques in the treatment of acousticmnestic aphasia patients. In the theoretical part of the article, the language and communication deficits occurring in the acoustic-mnestic aphasia are described. The basic assumptions and mechanisms of neurological music therapy were also presented, as well as the neuromuscular therapeutic techniques were briefly characterized and divided into three groups due to the area of influence (sensomotor, speech therapy and cognitive). Next, a case study of a patient with acoustic-mnestic aphasia was presented. Based on the characteristics and description of linguistic and communication disorders of the patient, appropriate cognitive techniques of neurological musicotherapy were selected and their use in the therapy of the described patient was described.
\end{abstract}

KeY wORDs: neurological music therapy, speech disorders, speech therapy, acoustic and mnestic aphasia, cognitive techniques

\section{Introduction}

There are many methods for the treatment of aphasia, but it is obvious that the best method is one that gives the fastest possible results and brings joy to the patient. The most important rule in planning the aphasia therapy is a reliable diagnosis, thanks to which the speech therapist will know what type of linguistic disorders he is dealing with and how to properly program the therapy and choose appropriate techniques and methods for it.

One of the types of aphasia is the acoustic-amnesic aphasia, which is characterized by, among others, loss of memory traces in auditory modality, which is manifested by difficulties in updating names. There are often problems in understanding longer speech, repetition and speaking - due to the inability to remember individual elements of the text (Panasiuk, 2012b). Considering the deficits- 
described above, it is obvious that speech therapy in auditory-amnesic disorders is primarily aimed at shaping the ability to preserve a complex of elements in auditory memory (Styczek, 1981, pp. 254-286).

This article presents a case study of a man with acoustic-amnesic aphasia, in whom several selected cognitive techniques of neurological music therapy were implemented. However, before I move to the description of these techniques and the course of therapy of the above-mentioned patient, I would like to explain what neurological music therapy is in general.

\section{Neurological music therapy - definition, goals and assumptions}

Neurological Music Therapy (NMT) - is the therapeutic use of music in cognitive, sensory and motor dysfunctions caused by damage or diseases of the nervous system (Thaut, 2005, p. 12). It is used in neurological speech disorders. NMT includes 20 standardized clinical techniques that are divided into: cognitive, speech therapy and sensomotor. Michael $\mathrm{H}$. Thaut is the creator of the techniques - a music therapist and neuropsychologist, who, together with a group of colleagues at the Centre for Biomedical Research in Music, operating at the State University of Colorado, has been conducting research on the use of music in therapy for many years.

Neurological music therapy stimulates those areas of the brain by improving the functioning of which the patient will improve his quality of life. It was created based on several neurophysiological theories. One of its assumptions is the need for learning and training through music and rhythm in the form of stimulation (especially when it comes to improving cognitive, verbal and motor functions). "NMT refers to the assumptions of neurorehabilitation and is treated as one of the factors that may affect the paving of new nerve connections in the brain according to the theory of its plasticity" (Kinalski, 2008, p. 26). Neurological paving is based on auditory stimulation to enhance the patient's motor, cognitive and language functions. Adherence to the above-mentioned assumptions in the course of music therapy allows to observe its positive effects (Kinalski, 2008, p. 26). Neurological music therapy includes the cooperation of many specialist doctors, physiotherapists, speech therapists, occupational therapists and music therapists. Therefore, it is necessary to work in an interdisciplinary team in this area (Baker \& Tamplin, 2006, p. 18).

Neurological music therapy techniques have their neurological basis, which is based on "neurophysiological mechanisms of the need to process information in both cerebral hemispheres. It is based on the theory of the use of sensory stimuli and activation of rhythmic involvement" (Ruda \& Trypka, 2013, p. 20). Special- 
ists who are not music therapists may be able to provide some elements of neurological music therapeutic techniques. This applies to, for example, occupational therapists (speech therapists) or physiotherapists (Ruda \& Trypka, 2013, p. 20).

\section{Principles of music operation in neurological music therapy}

Thaut identifies four mechanisms of music operation in neurological rehabilitation. He defines the first one as "rhythmic stimulation and entrainment", i.e. alignment with "musical pulsation, synchronization of biological rhythms with musical ones [...] on the basis of acoustic resonance" (Galińska, 2015, p. 837). Another mechanism is the "processing of information contained in patterns" where music is a complex time stimulus that is organized into various types of patterns. In turn, the third one is "neurological processing of varied musical parameters", which consists in allowing access to damaged areas and compensating for their functions by alternative connections. The last mechanism is the "affectiveaesthetic response", where emotions and meanings are expressed through music, which is a strong impulse to receive its symbolic, internal structure of musical elements (Galińska, 2015, p. 837).

NMT techniques are used, among others, to relieve the symptoms of aphasia, pragnosia, Parkinson's and Huntington's diseases, cerebral palsy, Alzheimer's disease, autism and other neurological diseases that affect cognitive function, as well as movement and communication (e.g. multiple sclerosis, muscular dystrophy, etc.). NMT includes neurological, neuropediatric, neuropsychiatric, neurogeriatric and neurodevelopmental rehabilitation (Thaut, McIntosh, \& Hoemberg, 2015, p. 2).

\section{Sensorimotor techniques}

NMT through sensorimotor training give the opportunity to build a taskoriented therapy. In these techniques, therapists try to teach patients activities that are similar to those of everyday life. The task form facilitates understanding and also performing a given activity. Among sensorimotor techniques, Thaut distinguished the following: rhythmic auditory stimulation, which is used to develop the correct gait pattern for music. While the goal of the therapeutic instrumental music performance is to stimulate functional movement patterns in speech therapy. In turn, patterned sensory enhancement involves stimulation 
of the upper and lower torso, limbs or the whole body, e.g. through grip exercises (Bukowska, 2012, p. 170).

\section{Speech therapy techniques}

Patients after neurological incidents who suffer from speech disorders, thanks to speech training can successfully improve their speech. Within neurological music therapy, 8 speech therapy techniques can be distinguished, which include various types of verbal communication damage (Bukowska, 2012, p. 170). The most popular one is the melodic intonation therapy, which is used in patients diagnosed with motor aphasia. The essence of the technique is that through singing and movement (e.g. of the hand), it helps the patient to liquefy his speech, as well as to rebuild it completely (Thaut \& Hoemberg, 2014, p. 246).

In turn, musical speech stimulation allows to stimulate the natural speech pattern, among others by playing musical rhymes that the patient likes. Rhythmic speech cueing is a technique that aims, among others, at improvement of patient's motor planning with the inability to perform precise movements, e.g. writing, sewing.

Improvement of the patient's articulation and strengthening of their voice strength is provided by vocal intonation therapy. In therapeutic singing, the most important aspect of the technique is that it can be used to treat various neurological disorders and is a supportive technique. Oral motor and respiratory exercises are used to improve articulation control and respiratory strength, as well as to improve the function of the speech apparatus.

The speech therapy technique, which is dedicated to, among others, children with speech delay, is the developmental speech and language training through music. In its essence, it uses a combination of music and movement to, among others, improve orientation in space as well as improve overall patient communication. In turn, the symbolic communication training through music, thanks to the use of musical improvisation, allows you to stimulate conversations (Thaut, 2005, p. 111).

\section{Cognitive techniques}

Cognitive training allows stimulation of perception and cognitive impairment. For the purposes of the article, selected cognitive techniques will be thoroughly 
discussed and presented in the case study of a patient with acoustic-amnesic aphasia. Four subgroups can be distinguished among them:

1. Techniques to improve attention and perception - conducted, among others, in order to orient the patient towards himself, other people, and the place and time, or to train divisibility, continuity and variability of attention. The following techniques can be distinguished in this group: musical sensory orientation training, musical neglect training, musical attention control training and auditory perception training.

2. Techniques to improve memory - music is used here to remember, e.g. names, surnames or other words, through their rhythmical repetition. The techniques classified in this category include: musical mnemonic training, associative mood and memory training.

3. Techniques to improve executive functions - exercises are mainly based on improvisation, it is a musical executive functions training.

4. Techniques to improve psychosocial behaviour - they are aimed at strengthening proper emotional expression. Within this group, you can distinguish musical psychotherapy and counselling.

\section{Aphasia - terminology, classification}

Despite the existence of many definition of aphasia that can be found in the literature, the most frequently cited one is the definition of Mariusz Maruszewski (1966), according to whom "aphasia is caused by organic damage to relevant brain structures, partial or complete disruption of mechanisms that program speech functions in a man who has already had mastered these activities before" (p. 26). Maruszewski in his formula takes into account the pathomechanism of the disorder, impaired functions and location of the damage. He also indicates the degree and depth of language disorder (Panasiuk, 2012a, p. 69). This is probably why this definition is cited most often.

There are many forms of aphasia, hence there are many classifications of aphasia in the literature. For the purposes of this publication, the aphasia classification created by Aleksander Łuria was used. He distinguished 6 factors that, implemented through specific areas of the cerebral cortex, determine the correct course of speech activity; these are:

1. phonematic hearing - implemented through the Wernicke area, which is located in the posterior part of the upper temporal gyrus in the left hemisphere of the brain;

2. auditory verbal memory - associated with the functioning of the posterior temporal lobe below the Wernicke area; 
3. a sense of arrangement of elements of the articulatory apparatus based on the processing of sensory (somaesthetic) feedback generated during the utterance of the text - this activity is regulated by the cortical structures of the parietal lid;

4. sequential synthesis (organization during movements of the articulation apparatus) - Broca's area in the lower left pre-muscular area is responsible for it;

5. simultaneous synthesis - carried out by the cerebral cortex lying on the border of the parietal, occipital and temporal lobes;

6. internal speech - belonging to the area of the left frontal lobe, located forward from the Broca's area (Herzyk, 1997, pp. 90-95).

Based on the above-mentioned factors, Łuria distinguished the following forms of aphasia:

- kinetic, efferent or centre-motor aphasia (resulting from damage to sequential synthesis);

- kinaesthetic, afferent or centre-motor aphasia (caused by disturbed sensation of arrangement of elements of the articulatory apparatus);

- motor-dynamic aphasia (resulting from an internal speech disorder);

- acoustic-gnostic aphasia (caused by a phonematic hearing disorder);

- acoustic-amnesic aphasia (resulting from auditory verbal memory disruptions);

- semantic aphasia (resulting from simultaneous synthesis disorder) (Panasiuk, 2012a, p. 69).

\section{Acoustic-amnestic aphasia - pathomechanism, neuroanatomical and functional correlations}

Acoustic-amnesic aphasia can occur as the primary form of aphasia. Nominal disorders may occur as a result of difficulties in remembering names or difficulties in recognizing objects, as is the case with Alzheimer's dementia. It can also occur as primary progressive aphasia, which is most often associated with frontal-temporal dementia (Pąchalska, 2008). Acoustic-amnesic aphasia occurs as a result of trauma to the mid-posterior part of the left temporal lobe in such a way that there is no complete damage to the Wernicke area.

Temporal lobes are associated primarily with hearing. Nerve impulses from auditory receptors are also added here. They are subjected to further analysis in the auditory associative cortex located in the posterior part of the upper temporal convolvulus (Wernicke area). This area is associated with understanding verbal statements, which is enabled by numerous cortical connections with other sensory systems. Organized memory in the form of a neural network including temporal lobes and subcortical structures is particularly important (Pąchalska, 1999, p. 89). 


\section{Acoustic-amnesic aphasia - language and cognitive impairment}

As mentioned at the beginning of the article, the main deficit in acousticamnesic aphasia is a disorder of auditory verbal memory, which is defined as "the ability to remember words and sentences heard, related to the functioning of the posterior temporal lobe below the Wernicke area" (Panasiuk, 2012a, p. 71). As a result, the ability to understand longer statements is disturbed a sick person does not have difficulty in differentiating phonemes, but has difficulty in keeping a larger amount of data in focus and memory (without having general memory problems).

There are also problems in this type of aphasia, including the repetition of fragments of statements that increase with the increase of incoming information - the patient may correctly differentiate and repeat individual sounds in isolation, and it will be difficult for him to imitate more complicated elements. A patient with acoustic-amnesic aphasia will easily repeat the word in isolation, but a series of three or four words will be problematic for him (especially when he is to remember their order).

There are difficulties with naming objects, so it can be helpful to suggest initial fragments of words. "Difficulties in finding words (anomia) occur in virtually all types of aphasia, however, with damage to the left angular gyrus often lead to amnesic disorders, as with damage to the second temporal gyrus" (Pąchalska, 1999, p. 94). Patients also face difficulties in developed speech and verbal thinking, which are subject to major disorders due to impermanence of verbal traces (Euria, 1976, p. 37). In addition, this type of aphasia may include:

- paraphasia - word substitution;

- periphrases - descriptions (most often functional) of words;

- pauses - empty episodes on the vocal wave (occur especially when the patient is talking about general, non-personal topics);

- neologisms and empty speech.

However, the following language, communication and cognitive skills are preserved in acoustic-amnesic aphasia:

- phonemic hearing; understanding of words;

- correct speech generation;

- fairly fluent speech;

- correct articulation;

- visual memory;

- reading aloud and writing.

In acoustic-amnesic aphasia, the compensatory role in the absence of semantic coherence is played by grammatical and pragmatic coherence in text-forming activities (Panasiuk, 2012a, p. 89). 


\section{Description of cognitive techniques in the therapy of a patient with acoustic-amnesic aphasia}

The main goal of the therapeutic measures taken was to improve the patient's dysfunction associated with the diagnosed acoustic-amnesic aphasia. Data on the subject undergoing therapy come from an interview with the family, as well as from the analysis of medical records, but also from the speech therapy diagnosis. Based on the results of the study, a therapy plan with the use of cognitive techniques of neurological music therapy was described, and its course was characterized.

\section{Characteristics of the examined person}

Mr. Andrzej is 58 years old. He has higher education, he is a notary; married, with three children. He lives in Poland in a medium-sized city in Pomerania. Two years ago, at the age of 56, the patient was in a car accident, which resulted in damage to the temporal lobe of the left hemisphere of the brain. As a result of this event, the man suffered from right-sided hemiparesis and acoustic-amnesic aphasia.

According to his wife's interview, after the accident, Mr. Andrzej stayed in the hospital for 5 weeks. After a period of hospitalization, the speech therapist diagnosed him with acoustic-amnesic aphasia. In the speech therapy documentation of that period, you can read that the man had difficulty in remembering longer sentences that other people spoke to him and was unable to recall specific events, e.g. from his childhood. In addition, his mood was reduced and he was depressed.

Since the man was included in speech therapy, therapists who worked with him have managed to improve his speech in terms of prosody - the patient's speech is fluent. Mr. Andrzej does not replace words he does not know with extensive descriptions, but he searches his memory with the appropriate name of the given designation.

The patient is still under speech therapy, but he still has trouble remembering a statement that has more than three sentences. Nor can he freely watch the news on TV, because he cannot remember the news he hears. There are constant difficulties with remembering complicated words, in particular legal terms, which causes a man great mental discomfort. Problems are also apparent at the level of remembering the names of everyday objects, such as: telephone, lamp; it also takes a lot of effort of the patient to focus his attention on the task at hand. 


\section{Objectives and methods of the speech therapy program and its course}

After a thorough analysis of medical and speech therapy documentation, my own observation of the patient and a conversation with a speech therapist about his language and communication disorders, I proposed to Mr. Andrzej therapy with specific cognitive techniques of neurological music therapy. Due to the patient's persistent problems, the following therapeutic goals were set:

- attention and perception improvement;

- improvement of attention retention.

The following were selected to work on improving the patient's memory:

- Musical Mnemonic Training (MMT);

- Associative Mood and Memory Training (AAMT).

The following were used to work on the attention and perception:

- Musical Sensory Orientation Training (MSOT).

In order to improve patient attention, the Musical Attention Control Training (MACT) was used.

Therapeutic sessions were held at the patient's home, three times a week for 60 minutes, for a period of 12 weeks. During therapy, percussion instruments were used, such as: drums, tambourine and maracas, as well as a keyboard.

\section{Work on improving memory}

The first technique used in the man's therapy was the Music Memory Training (MMT), the essence of which is to use music exercises to be able to address various functions, e.g. coding and decoding/recalling memory. Musical stimuli can be used as a memory template in a song, singing or rhyme or to facilitate learning other information. This is done by sequencing and organizing information in temporarily structured patterns or fragments (Thaut, 2005, p. 44).

Exercises with this technique consisted of placing the drum in front of the patient and asking him to make a constant rhythm while simultaneously saying the agreed word, phrase or sentence. During the first therapy session with Mr. Andrzej, I chose the Latin sentence audiatur et altera pars, which means: "let the other party be heard". The phrase was repeated 20 times in a constant rhythm during each therapy session. During the next 11 weeks of therapy, the patient memorized another 7 Latin sentences: three consisting of 5 words, two consisting of 6 words and two consisting of 8 words. Another cognitive technique from the group aimed at improving memory used during the therapy ses- 
sion was the Associative Mood and Memory Training (AAMT). Here, music plays an auxiliary role in remembering, e.g. of words, sentences, by creating a positive mood. The properties of music also help to bring back good memories (Bukowska, 2012, p. 170).

The whole family of the man, as well as himself, were fans of the T-Love band. During one of the therapy sessions, I played a well-known song of the band to $\mathrm{Mr}$. Andrzej - "Nie, nie, nie". The patient admitted that there were only nice memories associated with this song. When the song was playing in the background, I asked Mr. Andrzej to put together a rather complicated picture story, which consisted of 8 elements. The patient managed to put 5 elements together correctly the first time, but during the third therapy session using this song, he managed to put together all elements of the story and he was able to tell the whole story written on the cards. At the fifth meeting, the patient presented me his repertoire of his 30 favourite songs, which accompanied the subsequent therapy sessions when we, among others, did crosswords or I asked Mr. Andrzej to do exercises to improve his verbal fluency.

\section{Work on improving attention and perception}

Musical Sensory Orientation Training (MSOT) is used to improve the patient's orientation towards himself, another person, and place and time. With it you can also develop the ability to be oriented in everyday objects (Ruda \& Trypka, 2013, p. 159). The work with this technique consisted in the fact that during the therapy session I used the "Panie Janie" melody, for example, to sing the phrase: "where is the vase?" several time. The task of Mr. Andrzej was to answer my question by singing, using the same melody, and also pointing his finger to the place where the object was standing.

I also used this technique when using the pictorial material. It consisted in singing to the patient, e.g., "show me where the carpet is" to any melody, and the task of Mr. Andrzej was, similarly to the previous exercise, to point to that object - this time in the picture - while singing. This technique can be graded in terms of difficulty, e.g. by asking the patient to choose a different melody when answering the question than the one the therapist is humming at first. 


\section{Work on maintaining attention}

Musical Attention Control Training (MACT) aims to train the patient's selectivity, continuity, divisibility and variability (Ruda \& Trypka, 2013, p. 159). Exercises conducted with this technique consisted in the fact that I asked Mr. Andrzej to freely sing a melody he liked (but the one I also knew), using maracas or tambourine (in order to set the rhythm to his singing). The patient chose the song "Cicha woda brzegi rwie" by Zbigniew Kurtycz. (fragment of text below):

A stream flowed through the green forest

A hundred-stone boulder lay by the shore.

A stream was flowing. Some time has passed

One hundred boulder is missing

The stream flows as it flowed.

Chorus:

Quiet water rims...

When Mr. Andrzej started singing the chorus, I started singing the same song, but from the first verse playing the melody on the keyboard. This was to check whether the patient would be able to focus his attention on what he is currently singing and would be able to continue to set the appropriate rhythm. This exercise had a significant impact on the ability to focus attention of $\mathrm{Mr}$. Andrzej when performing other tasks and speech therapy exercises (without the use of music).

\section{Final remarks about the therapy}

The neurological music therapy techniques mentioned and described above are the picture of therapeutic work with a patient with acoustic-amnesic aphasia. It is worth remembering that the final result of therapy depends on the course of the disease, but also the patient's motivation and the degree of his involvement in the improvement process. During the therapy, Mr. Andrzej did all exercises with due diligence. After 12 weeks of therapy, the patient's ability to remember a greater amount of verbal material has significantly increased. The man solved more and more difficult crosswords, remembered a lot more information than before the therapy, e.g. watching TV or reading a newspaper. After the therapy, the speech therapist of Mr. Andrzej stated that his perception and focus during speech therapy exercises without using music have improved. 


\section{Summary}

For patients with acoustic-amnesic aphasia, cognitive techniques are motivation to work on cognitive processes, such as attention or memory, as well as to perform other mental operations. They also allow the improvement of patients' linguistic functioning, and thus - their quality of life is also improved. In the application of cognitive techniques, as well as all other neurological music therapy techniques, it is very important to choose songs, their parameters, harmony and sound (Paszkiewicz-Mes, 2013). Equally important is the careful selection of performers and musical instruments, which should depend on the type of illness, the patient's personality type, his mental state and therapeutic goals that we want to achieve.

\section{Bibliography}

BAKer, F., \& TAMPLIN, J. (2006). Music therapy methods in neuro-rehabilitation. A clinician's manual. London: Jessica Kingsley Publishers.

Bukowska, A. (2012). Muzykoterapia neurologiczna. In: K. STACHYRA (Ed.), Modele, metody i podejścia w muzykoterapii (pp. 165-178). Lublin: Wydaw. Uniwersytetu Marii Curie-Skłodowskiej.

Galı́́ska, E. (2015). Znaczenie muzykoterapii w rehabilitacji neurologicznej. Psychiatria Polska, $49(4), 835-846$.

Herzyk, A. (1997). Taksonomia afazji. Kryteria klasyfikacji i rodzaje zespołów zaburzeń. Audiofonologia, X, 83-101.

Kinalski, R. (2008). Neurofizjologia kliniczna dla neurorehabilitacji. Podręcznik dla studentów i absolwentów wydziałów fizjoterapii. Wrocław: MedPharm.

ŁURIA, A.R. (1976). Problemy neuropsychologii i neurolingwistyki. Warszawa: PWN.

Maruszewski, M. (1966). Afazja. Zagadnienia teorii i terapii. Warszawa: PWN.

Panasiuk, J. (2012a). Afazja a interakcja. Tekst, metaTekst, konTekst. Lublin: Wydaw. Uniwersytetu Marii Curie-Skłodowskiej.

Panasiuk, J. (2012b). Diagnoza logopedyczna w przebiegu chorób neurologicznych u osób dorosłych. In: E. Cza plewska, \& S. Milewski (Ed.), Diagnoza logopedyczna. Podręcznik akademicki (s. 263-321). Sopot: Gdańskie Wydaw. Psychologiczne.

Paszkiewicz-Mes, E. (2013). Muzykoterapia jako metoda wspomagająca leczenie. Hygeia Public Health, 48(2), 168-176.

Pąchalska, M. (1999). Afazjologia. Warszawa-Kraków: PWN.

PĄchalska, M. (2008). Patogeneza i neuropsychologiczna diagnostyka afazji. In: Ł. Domańska, \& A.R. Borkowska (Ed.), Podstawy neuropsychologii klinicznej (pp. 153-191). Lublin: Wydaw. Uniwersytetu Marii Curie-Skłodowskiej.

RUDA, K., \& TRYPKA, E. (2013). Terapeutyczne znaczenie muzyki dla regulowania zaburzeń zachowania w rehabilitacji pacjentów chorujących na otępienie. Psychogeriatria Polska, 10(4), 157-164.

STYCzeK, I. (1981). Logopedia. Warszawa: PWN. 
Thaut, M.H. (2005). Rhythm, Music, and the Brain: Scientific Foundations and Clinical Applications. New York: Routledge.

Thaut, M.H., \& Hoemberg, V. (2014). Oxford Handbook of Neurologic Music Therapy. Oxford: Oxford University Press.

Thaut, M.H., McIntosh, G.C., Hoemberg, G. (2015). Neurobiological foundations of neurologic music therapy: rhythmic entrainment and the motor system. Frontiers in Psychology, 5, 1-6. 
„Logopedia Silesiana”, t. 7, ISSN 2391-4297

DOI 10.31261/LOGOPEDIASILESIANA.2018.08.20

(c) BY-SA

\author{
Aneta Syta \\ Zakład Logopedii i Emisji Głosu, \\ Uniwersytet Warszawski \\ (D) 0000-0001-7487-4083
}

\title{
Wybrane techniki kognitywne muzykoterapii neurologicznej w terapii afazji akustyczno-mnestycznej Opis przypadku
}

\begin{abstract}
Aвstract: Music is able to stimulate the human brain at different levels, resulting in greater durability of treatment results, as well as the overall health of patients is improved. The aim of the article is to present the use of cognitive neurological music therapy techniques in the treatment of acousticmnestic aphasia patients. In the theoretical part of the article, the language and communication deficits occurring in the acoustic-mnestic aphasia are described. The basic assumptions and mechanisms of neurological music therapy were also presented, as well as the neuromuscular therapeutic techniques were briefly characterized and divided into three groups due to the area of influence (sensomotor, speech therapy and cognitive). Next, a case study of a patient with acoustic-mnestic aphasia was presented. Based on the characteristics and description of linguistic and communication disorders of the patient, appropriate cognitive techniques of neurological musicotherapy were selected and their use in the therapy of the described patient was described.
\end{abstract}

KEY WORDs: neurological music therapy, speech disorders, speech therapy, acoustic and mnestic aphasia, cognitive techniques

\section{Wprowadzenie}

Istnieje wiele metod do terapii afazji, lecz oczywistym jest, że najlepsza metoda to taka, która daje możliwie najszybsze efekty i przynosi radość pacjentowi. Najważniejszą zasadą w planowaniu terapii afazji jest rzetelnie postawiona diagnoza, dzięki której logopeda będzie wiedział, z jakim typem zaburzeń językowych ma do czynienia i jak odpowiednio zaprogramować terapię i dobrać do niej stosowne techniki i metody.

Jednym z rodzajów afazji jest afazja akustyczno-mnestyczna, która charakteryzuje się m.in. utratą śladów pamięciowych w modalności słuchowej, co przejawia się trudnościami w aktualizacji nazw. Często występują problemy w rozumieniu 
dłuższych wypowiedzi, powtarzaniu i mówieniu - ze względu na niemożność utrzymania w pamięci poszczególnych elementów tekstu (Panasiuk, 2012b). Biorąc pod uwagę opisane wyżej deficyty, oczywistym jest, że postępowanie logopedyczne przy zaburzeniach słuchowo-mnestycznych ma na celu przede wszystkim kształtowanie zdolności zachowywania kompleksu elementów w pamięci słuchowej (Styczek, 1981, s. 254-286).

W niniejszym artykule przedstawiono studium przypadku mężczyzny $z$ afazją akustyczno-mnestyczną, u którego w terapii wdrożono kilka wybranych technik kognitywnych muzykoterapii neurologicznej. Zanim jednak przejdę do opisu tychże technik oraz przebiegu terapii wyżej wymienionego pacjenta, pragnę przybliżyć, czym w ogóle jest muzykoterapia neurologiczna.

\section{Muzykoterapia neurologiczna - definicja, cele oraz założenia}

Muzykoterapia neurologiczna (Neurologic Music Therapy - NMT) - to terapeutyczne wykorzystanie muzyki w poznawczych, czuciowych i ruchowych dysfunkcjach wywołanych uszkodzeniami bądź chorobami układu nerwowego (Thaut, 2005, s. 12). Stosowana jest w zaburzeniach mowy pochodzenia neurologicznego. NMT obejmuje 20 wystandaryzowanych technik klinicznych, które dzielą się na: kognitywne, logopedyczne oraz sensomotoryczne. Twórcą technik jest Michael H. Thaut - muzykoterapeuta i neurofizjolog, który razem z grupą współpracowników w Centrum Badań Biomedycznych w Muzyce (The Center for Biomedical Research in Music), działającym przy Uniwersytecie Stanowym w Kolorado, od wielu lat prowadzi badania nad wykorzystaniem muzyki w terapii.

Neuromuzykoterapia stymuluje te obszary mózgu, dzięki poprawie funkcjonowania których pacjent poprawi swoją jakość życia. Została stworzona w oparciu o kilka neurofizjologicznych teorii. Jednym z jej założeń jest potrzeba uczenia się i treningu za pośrednictwem muzyki i rytmu w formie stymulacji (szczególnie jeśli chodzi o usprawnianie funkcji poznawczych, werbalnych oraz ruchowych). „NMT odnosi się do założeń neurorehabilitacji i traktowana jest jako jeden z czynników mogących wpłynąć na torowanie się nowych połączeń nerwowych w mózgu zgodnie z teorią jego plastyczności” (Kinalski, 2008, s. 26). Neurologiczne torowanie polega na stymulacji słuchowej mającej na celu wzmocnienie motorycznych, poznawczych i językowych funkcji pacjenta. Stosowanie się do wyżej wymienionych założeń w przebiegu muzykoterapii pozwala obserwować pozytywne jej skutki (Kinalski, 2008, s. 26). Muzykoterapia neurologiczna obejmuje współpracę wielu specjalistów-lekarzy, fizjoterapeutów, logopedów, terapeutów zajęciowych oraz muzykoterapeutów. Konieczna jest zatem w tym obszarze praca w zespole interdyscyplinarnym (Baker \& Tamplin, 2006, s. 18). 
Techniki neuromuzykoterapii mają swoją neurologiczną podstawę, która opiera się na „neurofizjologicznych mechanizmach konieczności przetwarzania informacji w obu półkulach mózgowych. Jej bazą jest teoria stosowania bodźców czuciowych oraz uruchomienie zaangażowania rytmicznego" (Ruda \& Trypka, 2013, s. 20). Specjaliści, którzy nie są muzykoterapeutami, mogą prowadzić niektóre elementy technik neuromuzykoterapeutycznych. Dotyczy to np. terapeutów zajęciowych (logopedów) czy też fizjoterapeutów (Ruda \& Trypka, 2013, s. 20).

\section{Zasady działania muzyki w muzykoterapii neurologicznej}

Thaut identyfikuje cztery mechanizmy działania muzyki w rehabilitacji neurologicznej. Pierwszy z nich definiuje jako „stymulację rytmiczną i entrainment”, czyli zestrojenie $\mathrm{z}$ „pulsacją muzyczną, synchronizację rytmów biologicznych z muzycznymi [...] na zasadzie rezonansu akustycznego" (Galińska, 2015, s. 837). Kolejnym mechanizmem jest "przetwarzanie informacji ujętej we wzory” - gdzie muzyka stanowi złożony bodziec czasowy, który jest zorganizowany w różnego rodzaju wzory. Trzecim z kolei jest „przetwarzanie neurologiczne zróżnicowanych parametrów muzycznych", które polega na tym, że pozwala na dostęp do rejonów uszkodzonych i kompensacyjne przejęcie ich funkcji przez alternatywne połączenia. Ostatni mechanizm to „odpowiedź afektywno-estetyczna”, gdzie emocje i znaczenia wyrażane są poprzez muzykę, która jest silnym impulsem do odbioru jej symbolicznej, wewnętrznej struktury elementów muzycznych (Galińska, 2015, s. 837).

Techniki NMT wykorzystywane są m.in. w łagodzeniu objawów afazji, pragnozji, chorób Parkinsona i Huntingtona, porażenia mózgowego, choroby Alzheimera, autyzmu i innych chorób neurologicznych, które wpływają na funkcje poznawcze, a także ruch i komunikację (np. stwardnienie rozsiane, dystrofia mięśniowa itp.). NMT obejmuje rehabilitację neurologiczną, neuropediatryczną, neuropsychiatryczną, neurogeriatryczną i neurorozwojową (Thaut, McIntosh, \& Hoemberg, 2015, s. 2).

\section{Techniki sensomotoryczne}

NMT poprzez techniki sensomotoryczne (sensorimotor training) daje możliwość budowania terapii, która jest zorientowana na zadania. W technikach tych terapeuci starają się uczyć pacjentów aktywności, które są podobne do tych 
z dnia codziennego. Forma zadaniowa ułatwia zrozumienie, a także wykonanie danej aktywności. Spośród technik sensomotorycznych Thaut wyróżnił następujące: technika rytmicznej stymulacji słuchowej (rhytmic auditory stimulation), która służy do tego, aby wypracować prawidłowy wzorzec chodu przy muzyce. Celem zaś terapeutycznego grania na instrumentach muzycznych (therapeutic instrumental music performance) jest stymulowanie funkcjonalnych wzorców ruchowych w terapii logopedycznej. Z kolei wzmacnianie wzorców czuciowych (patterned sensory enhancement) obejmuje stymulację górnego i dolnego tułowia, kończyn lub całego ciała, np. poprzez ćwiczenia chwytu (Bukowska, 2012, s. 170).

\section{Techniki logopedyczne}

Pacjenci po incydentach neurologicznych, którzy cierpią na zaburzenia mowy, dzięki technikom logopedycznym (speech/language training) mogą z powodzeniem doskonalić swoją mowę. W obrębie muzykoterapii neurologicznej można wyróżnić 8 technik logopedycznych, które obejmują różne typy uszkodzenia komunikacji werbalnej (Bukowska, 2012, s. 170). Najbardziej znaną jest terapia melodyczno-intonacyjna (melodic intonation therapy), która stosowana jest najczęściej u pacjentów ze zdiagnozowaną afazją ruchową. Istotą techniki jest to, że poprzez śpiew i ruch (np. ręki) pozwala pomóc pacjentowi w upłynnieniu jego mowy, a także w całkowitym jej odbudowaniu (Thaut \& Hoemberg, 2014, s. 246).

Z kolei muzyczna stymulacja mowy (musical speech stimulation) pozwala na stymulowanie naturalnego wzorca mowy, m.in. poprzez granie na instrumentach lubianych przez pacjenta rymowanek muzycznych. Rytmiczne planowanie mowy (rhytmic speech cueing) to technika, która ma na celu m.in. poprawę planowania ruchowego u pacjenta $\mathrm{z}$ niemożnością wykonywania ruchów precyzyjnych, np. pisania, szycia.

Poprawie artykulacji pacjentów oraz wzmocnieniu siły ich głosu służy terapia głosowo-intonacyjna (vocal intonation therapy). W śpiewaniu terapeutycznym (therapeutic singing) najważniejszym aspektem techniki jest to, iż może ona służyć w terapii różnych zaburzeń neurologicznych i jest techniką wspomagającą. Ćwiczenia oddechowe i motoryczne ust (oral motor and respiratory exercises) wykorzystuje się w terapii do poprawy kontroli artykulacyjnej i siły oddechowej, jak również do poprawy funkcji aparatu mowy.

Techniką logopedyczną, która jest dedykowana m.in. dzieciom z alalią, jest rozwojowy trening mowy przy muzyce (developmental speech and language training through music). W swej istocie wykorzystuje ona połączenie muzyki i ruchu do tego, aby m.in. poprawić orientację w przestrzeni, a także usprawnić ogólną komunikację pacjenta. Z kolei symboliczny trening komunikacyjny przy muzyce 
(symbolic communication training through music), dzięki wykorzystaniu improwizacji muzycznej, pozwala na stymulowanie konwersacji (Thaut, 2005, s. 111).

\section{Techniki kognitywne}

Techniki kognitywne (cognitive training) pozwalają na stymulację percepcji oraz zaburzeń poznawczych. Na potrzeby artykułu wybrane techniki kognitywne zostaną dokładnie omówione i przedstawione w opisie przypadku pacjenta z afazją akustyczno-mnestyczną. Wśród nich można wyróżnić cztery podgrupy: 1. Techniki służące poprawie uwagi i percepcji - prowadzone m.in. w celu orientacji pacjenta do siebie, innych osób oraz miejsca i czasu, czy też w celu trenowania podzielności, ciągłości i zmienności uwagi. W tej grupie można wyróżnić następujące techniki: muzyczny zmysłowy trening orientacyjny (musical sensory orientation training), muzyczny trening zespołu zaniedbywania (musical neglect training), muzyczny trening kontroli uwagi (musical attention control training) oraz słuchowy trening percepcyjny (auditory perception training).

2. Techniki służące poprawie pamięci - muzyka jest tu wykorzystywana do zapamiętywania np. imion, nazwisk czy innych słów, poprzez ich rytmiczne powtarzanie. Techniki klasyfikowane w tej kategorii to: muzyczny trening pamięci (musical mnemonic training), skojarzeniowy trening nastroju i pamięci (associative mood and memory training).

3. Techniki służące poprawie funkcji wykonawczych - ćwiczenia są oparte głównie na improwizacji, jest to muzyczny trening funkcji wychowawczych (musical executive functions training).

4. Techniki służące poprawie zachowań psychospołecznych - mają na celu wzmocnienie właściwej ekspresji emocjonalnej. W obrębie tej grupy wyróżnić można muzyczną psychoterapię i doradztwo (musical psychotherapy and counseling).

\section{Afazja - ustalenia terminologiczne, klasyfikacja}

Pomimo występowania wielu definicji afazji, które można znaleźć w literaturze, najczęściej przywoływaną jest definicja Mariusza Maruszewskiego (1966), według którego „afazja to spowodowane organicznym uszkodzeniem odpowiednich struktur mózgowych częściowe lub całkowite zaburzenie mechanizmów programujących czynności mowy u człowieka, który już uprzednio opanował te 
czynności” (s. 26). Maruszewski w swojej formule uwzględnia patomechanizm zaburzenia, zaburzone funkcje oraz lokalizację uszkodzenia. Wskazuje również na stopień i głębokości zaburzenia językowego (Panasiuk, 2012a, s. 69). Zapewne dlatego definicja ta jest najczęściej przywoływaną.

Postaci afazji jest bardzo wiele, stąd w literaturze przedmiotu można znaleźć wiele klasyfikacji afazji. Na potrzeby tej publikacji posłużono się klasyfikacją afazji stworzoną przez Aleksandra Łurię. Wyodrębnił on 6 czynników, które realizowane przez określone okolice kory mózgowej, warunkują prawidłowy przebieg czynności mowy; są to:

1. słuch fonematyczny - realizowany przez okolicę Wernickego, która zlokalizowana jest w tylnej części górnego zakrętu skroniowego w lewej półkuli mózgu;

2. słuchowa pamięć werbalna - wiążąca się z funkcjonowaniem tylnej części płata skroniowego, leżącej poniżej okolicy Wernickego;

3. czucie ułożenia elementów aparatu artykulacyjnego oparte na przetwarzaniu informacji zwrotnej czuciowej (somestetycznej) wytwarzanej podczas wypowiadania tekstu - czynność tę regulują struktury korowe wieczka ciemieniowego;

4. synteza sekwencyjna (organizacja w czasie ruchów aparatu artykulacyjnego) odpowiada za nią okolica Broca w dolnej części lewej okolicy przedruchowej;

5. synteza symultatywna - realizowana przez okolice kory mózgowej leżące na pograniczu płatów: ciemieniowego, potylicznego i skroniowego;

6. mowa wewnętrzna - przynależna okolicom lewego płata czołowego, położonym do przodu od okolicy Broca (Herzyk, 1997, s. 90-95).

Na podstawie wyżej wymienionych czynników Łuria wyróżnił następujące postaci afazji:

- afazję kinetyczną, eferentną lub ośrodkowo-ruchową (powstałą w wyniku uszkodzenia syntezy sekwencyjnej);

- afazję kinestetyczną, aferentną lub dośrodkowo-ruchową (spowodowaną zaburzeniem czucia ułożenia elementów aparatu artykulacyjnego);

- afazję motoryczno-dynamiczną (będącą wynikiem zaburzenia mowy wewnętrznej);

- afazję akustyczno-gnostyczną (wywołaną przez zaburzenie słuchu fonematycznego);

- afazję akustyczno-mnestyczną (powstałą w wyniku zakłóceń słuchowej pamięci werbalnej);

- afazję semantyczną (będącą skutkiem zaburzenia syntezy symultatywnej) (Panasiuk, 2012a, s. 69). 


\section{Afazja akustyczno-mnestyczna - patomechanizm, korelacje neuroanatomiczne i czynnościowe}

Afazja akustyczno-mnestyczna może występować jako pierwotna postać afazji. Zaburzenia nominacyjne mogą pojawić się w następstwie trudności w przypominaniu sobie nazw albo trudności w rozpoznawaniu przedmiotów, jak to się dzieje w przypadku otępienia typu Alzheimera. Może też wystąpić jako afazja pierwotna postępująca (primary progressive aphasia), która najczęściej towarzyszy otępieniu czołowo-skroniowemu (Pąchalska, 2008). Afazja akustyczno-mnestyczna pojawia się w wyniku urazu środkowo-tylnej części lewego płata skroniowego w taki sposób, że nie następuje pełne uszkodzenie ośrodka Wernickego.

Płaty skroniowe związane są przede wszystkim ze słyszeniem. Dochodzą tutaj impulsy nerwowe $\mathrm{z}$ receptorów słuchowych. Zostają one poddane dalszej analizie w słuchowej korze asocjacyjnej zlokalizowanej w tylnej części górnego zawoju skroniowego (okolicy Wernickego). Z obszarem tym związane jest rozumienie wypowiedzi słownych, co umożliwiają liczne połączenia korowe z innymi układami sensorycznymi. Szczególne znaczenie ma tutaj pamięć zorganizowana w postaci sieci neuronalnej obejmującej płaty skroniowe oraz struktury podkorowe (Pąchalska, 1999, s. 89).

\section{Afazja akustyczno-mnestyczna - zaburzenia czynności językowych i poznawczych}

Jak wspomniano na początku artykułu, głównym deficytem w afazji akustyczno-mnestycznej jest zaburzenie słuchowej pamięci słownej, która definiowana jest jako „zdolność utrzymywania w pamięci usłyszanych słów i zdań, związana $\mathrm{z}$ funkcjonowaniem tylnej części płata skroniowego, leżącej poniżej okolicy Wernickego" (Panasiuk, 2012a, s. 71). W związku z tym zaburzona jest zdolność rozumienia dłuższych wypowiedzi - osoba chora nie ma trudności z różnicowaniem fonemów, ale ma trudności z utrzymaniem w ognisku uwagi i w pamięci większej ilości danych słuchowych (przy czym wcale nie musi mieć ogólnych problemów z pamięcią).

$\mathrm{W}$ tym typie afazji występują również problemy m.in. z powtarzaniem fragmentów wypowiedzi, które nasilają się wraz ze wzrostem napływających informacji - chory może prawidłowo różnicować i powtarzać pojedyncze głoski w izolacji, zaś naśladowanie bardziej skomplikowanych elementów będzie sprawiało mu trudność. Pacjent $\mathrm{z}$ afazją akustyczno-mnestyczną bez trudu powtórzy wyraz w odosobnieniu, ale seria trzech czy czterech słów będzie już dla niego proble- 
matyczna (szczególnie gdy ma pamiętać o ich kolejności). Pojawiają się trudności dotyczące nazywania obiektów, w związku z czym pomocą może być podpowiadanie początkowych fragmentów wyrazów. „Trudności w znajdywaniu słów (anomia) występują właściwie we wszystkich rodzajach afazji, jednakże przy uszkodzeniach lewego zakrętu kątowego często prowadzą do wystąpienia zaburzeń mnestycznych, podobnie jak przy uszkodzeniu drugiego zakrętu skroniowego" (Pąchalska, 1999, s. 94). Pacjenci napotykają także trudności w mowie rozwiniętej i myśleniu werbalnym, które ulegają dużym zaburzeniom wskutek nietrwałości śladów słownych (Łuria, 1976, s. 37). Ponadto w tym typie afazji mogą występować:

- parafazje - zastępowanie wyrazów;

- peryfrazy - opisy (najczęściej funkcjonalne) słów;

- pauzy - puste odcinki na fali głosowej (występują szczególnie wtedy, kiedy pacjent rozmawia na tematy ogólne, nieosobiste);

- neologizmy oraz pustosłowie.

W afazji akustyczno-mnestycznej względnie zachowane są natomiast następujące sprawności językowe, komunikacyjne oraz poznawcze:

- słuch fonematyczny;

- rozumienie słów;

- poprawne generowanie mowy;

- mowa dość płynna;

- prawidłowa artykulacja;

- pamięć wzrokowa;

- głośne czytanie i pisanie.

W afazji akustyczno-mnestycznej rolę kompensacyjną przy braku spójności semantycznej pełnią w działaniach tekstotwórczych spójność gramatyczna oraz pragmatyczna (Panasiuk, 2012a, s. 89).

\section{Opis wykorzystanych technik kognitywnych $\mathrm{w}$ terapii pacjenta $\mathrm{z}$ afazją akustyczno-mnestyczną}

Głównym celem podjętych działań terapeutycznych było poprawienie dysfunkcji pacjenta związanych ze zdiagnozowaną afazją akustyczno-mnestyczną. Dane na temat osoby poddanej terapii pochodzą $z$ wywiadu $\mathrm{z}$ rodziną, jak również z analizy dokumentacji medycznej, a także diagnozy logopedycznej. W oparciu o wyniki badań opisano plan terapii z wykorzystaniem technik kognitywnych muzykoterapii neurologicznej, a także dokonano charakterystyki jej przebiegu. 


\section{Charakterystyka badanej osoby}

Pan Andrzej ma 58 lat. Posiada wykształcenie wyższe, jest notariuszem; żonaty, ma troje dzieci. Mieszka w Polsce w średniej wielkości mieście na Pomorzu. Dwa lata temu, w wieku 56 lat, pacjent uległ wypadkowi samochodowemu, w wyniku którego doznał uszkodzenia płata skroniowego lewej półkuli mózgu. Wskutek tego wydarzenia u mężczyzny nastąpił niedowład połowiczny prawostronny oraz afazja akustyczno-mnestyczna.

Jak wynika z wywiadu z żoną, po wypadku pan Andrzej przebywał w szpitalu 5 tygodni. Po okresie hospitalizacji logopeda zdiagnozował u niego afazję akustyczno-mnestyczną. W dokumentacji logopedycznej z tamtego okresu można przeczytać, że mężczyzna miał trudności w zapamiętywaniu dłuższych zdań, które wypowiadali do niego inni ludzie oraz nie był w stanie przywołać w pamięci konkretnych zdarzeń, np. z dzieciństwa. Ponadto jego nastrój był obniżony oraz miał stany depresyjne.

Od czasu objęcia mężczyzny terapią logopedyczną terapeutom, którzy z nim pracowali, udało się usprawnić jego mowę pod kątem prozodii - mowa pacjenta jest płynna. Pan Andrzej nie zastępuje również wyrazów, których nie zna, rozbudowanymi opisami, ale szuka w pamięci odpowiedniej dla danego desygnatu nazwy.

Pacjent cały czas objęty jest terapią logopedyczną, jednak nadal ma problem z zapamiętaniem wypowiedzi, która ma więcej niż trzy zdania. Nie może również swobodnie oglądać wiadomości w telewizji, ponieważ nie jest w stanie utrzymać $\mathrm{w}$ pamięci zasłyszanych informacji. Stale pojawiają się trudności z zapamiętywaniem skomplikowanych słów, a w szczególności terminów prawniczych, co powoduje u mężczyzny duży dyskomfort psychiczny. Problemy uwidaczniają się również na poziomie zapamiętywania nazw przedmiotów użytku codziennego, takich jak: telefon, lampa; sporo wysiłku sprawia pacjentowi także skupienie uwagi na wykonywanym zadaniu.

\section{Cele i metody programu terapii logopedycznej oraz jej przebieg}

Po wnikliwej analizie dokumentacji medycznej i logopedycznej, własnej obserwacji pacjenta oraz rozmowie z logopedą prowadzącym na temat jego zaburzeń językowych i komunikacyjnych, zaproponowałam panu Andrzejowi terapię konkretnymi technikami kognitywnymi muzykoterapii neurologicznej. $\mathrm{Z}$ uwagi na utrzymujące się problemy pacjenta wyznaczono następujące cele terapeutyczne: 
- poprawa pamięci;

- poprawa uwagi i percepcji;

- poprawa w utrzymaniu uwagi.

Do pracy nad poprawą pamięci pacjenta wybrano:

- Muzyczny Trening Pamięci (Musical Mnemonic Training - MMT);

- Skojarzeniowy Trening Nastroju i Pamięci (Associative Mood and Memory Training - AAMT).

Do pracy nad uwagą i percepcją wykorzystano:

- Muzyczny Zmysłowy Trening Orientacyjny (Musical Sensory Orientation Training - MSOT).

W celu poprawy w utrzymaniu uwagi pacjenta zastosowano:

- Muzyczny Trening Kontroli Uwagi (Musical Attention Control Training MACT).

Sesje terapeutyczne odbywały się w domu pacjenta, trzy razy w tygodniu po 60 minut, przez okres 12 tygodni. Podczas terapii wykorzystywano instrumenty perkusyjne, takie jak: bęben, tamburyno oraz marakasy, a także instrument klawiszowy - keyboard.

\section{Praca nad poprawą pamięci}

Pierwszą techniką zastosowaną w terapii mężczyzny był Muzyczny Trening Pamięci (MMT), którego istotą jest użycie ćwiczeń muzycznych do tego, by móc adresować różne funkcje, np. kodowanie i dekodowanie/przywoływanie pamięci. Bodźce muzyczne mogą być używane jako szablon pamięci w utworze, śpiewie czy rymie lub w celu ułatwienia uczenia się innych informacji. Dzieje się to za pomocą sekwencjonowania i organizowania informacji w tymczasowo ustrukturyzowanych wzorach lub fragmentach (Thaut, 2005, s. 44).

Ćwiczenia tą techniką polegały na ustawieniu przed pacjentem bębna i poproszeniu go o wybijanie stałego rytmu przy jednoczesnym, synchronicznym wypowiadaniu ustalonego słowa, zwrotu lub zdania. Podczas pierwszej sesji terapeutycznej z panem Andrzejem wybrałam sentencję łacińską audiatur et altera pars, co oznacza: „niech będzie wysłuchana i druga strona”. Zwrot powtarzany był 20 razy w stałym rytmie podczas każdej sesji terapeutycznej. Podczas kolejnych 11 tygodni terapii pacjent zapamiętał jeszcze 7 sentencji łacińskich: trzy składające się z 5 słów, dwie składające się z 6 słów oraz dwie składające się z 8 słów.

Kolejną techniką kognitywną z grupy służącej poprawie pamięci wykorzystaną podczas sesji terapeutycznej był Skojarzeniowy Trening Nastroju i Pamięci (AAMT). Muzyka pełni tu rolę pomocniczą w zapamiętywaniu np. słów, zdań, 
poprzez wywoływanie pozytywnego nastroju. Właściwości muzyki pomagają również przywołać dobre wspomnienia (Bukowska, 2012, s. 170).

Cała rodzina mężczyzny, jak i on sam byli fanami zespołu T-Love. Podczas jednej z sesji terapeutycznych włączyłam panu Andrzejowi znaną piosenkę zespołu - „Nie, nie, nie”. Pacjent przyznał, że z tym utworem wiążą się dla niego same miłe wspomnienia. Kiedy utwór leciał w tle, poprosiłam pana Andrzeja o to, by ułożył dość skomplikowaną historyjkę obrazkową, która składała się z 8 elementów. Pacjentowi za pierwszym razem udało się ułożyć poprawnie 5 elementów, ale przy trzeciej sesji terapeutycznej z wykorzystaniem opisanego utworu ułożył już wszystkie elementy układanki i był w stanie opowiedzieć całą historię zapisaną na kartach. Na piątym spotkaniu pacjent zaprezentował mi swój repertuar 30 ulubionych utworów, przy akompaniamencie których na kolejnych sesjach terapeutycznych m.in. rozwiązywaliśmy krzyżówki czy też prosiłam pana Andrzeja o wykonywanie ćwiczeń mających na celu poprawę fluencji słownej.

\section{Praca nad poprawą uwagi i percepcji}

Muzyczny Zmysłowy Trening Orientacyjny (MSOT) stosuje się w celu poprawy orientacji pacjenta co do siebie, drugiej osoby oraz miejsca i czasu. Dzięki niemu można wypracować również umiejętność orientowania się w przedmiotach codziennego użytku (Ruda \& Trypka, 2013, s. 159). Praca tą techniką polegała na tym, że podczas sesji terapeutycznej, np. na melodię „Panie Janie” śpiewałam pacjentowi kilkukrotnie zwrot: „gdzie jest wazon?”. Zadaniem pana Andrzeja było odpowiedzieć mi na pytanie, śpiewając, przy wykorzystaniu tej samej melodii, a także wskazując jednocześnie palcem na miejsce, w którym stał przedmiot.

Technikę tę wykorzystywałam również przy użyciu materiału obrazkowego. Polegało to na śpiewaniu pacjentowi na dowolną melodię zwrotu np. „pokaż, gdzie jest dywan", a zadaniem pana Andrzeja, analogicznie jak w poprzednim ćwiczeniu, było wskazanie przedmiotu - tym razem na ilustracji - wraz z użyciem śpiewu. Technikę tę można stopniować pod względem trudności, np. prosząc pacjenta, żeby podczas odpowiedzi na pytanie wybrał inną melodię niż ta, którą najpierw nuci terapeuta. 


\section{Praca nad utrzymaniem uwagi}

Muzyczny Trening Kontroli Uwagi (MACT) ma na celu trenowanie selektywności, ciągłości, podzielności i zmienności uwagi pacjenta (Ruda \& Trypka, 2013, s. 160). Ćwiczenia prowadzone tą techniką polegały na tym, że prosiłam pana Andrzeja o to, by swobodnie śpiewał lubianą przez siebie melodię (ale znaną również mi), używając przy tym marakasów lub tamburyna (w celu wybijania rytmu do swojego śpiewu). Pacjent wybrał piosenkę „Cicha woda brzegi rwie” Zbigniewa Kurtycza (poniżej fragment tekstu):

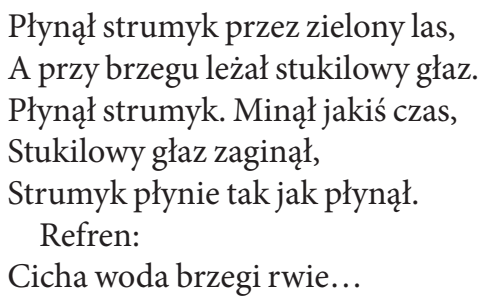

W momencie, w którym pan Andrzej zaczął śpiewać refren, ja zaczynałam śpiewać tę samą piosenkę, zaczynając od pierwszej zwrotki i grając jednocześnie na keyboardzie jej melodię. Miało to na celu sprawdzenie tego, czy pacjent zdoła skupić uwagę na tym, co aktualnie śpiewa i będzie przy tym w stanie dalej wybijać odpowiedni dla siebie rytm. To ćwiczenie miało znaczące przełożenie na umiejętność skupienia uwagi przez pana Andrzeja w przypadku wykonywania innych zadań i ćwiczeń logopedycznych (bez użycia muzyki).

\section{Uwagi końcowe o terapii}

Wymienione i opisane wyżej techniki neuromuzykoterapeutyczne są obrazem pracy terapeutycznej z pacjentem $\mathrm{z}$ afazją akustyczno-mnestyczną. Warto pamiętać, że ostateczny rezultat terapii zależy od przebiegu choroby, ale także motywacji pacjenta oraz stopnia jego zaangażowania się w proces usprawniania. Podczas terapii pan Andrzej wykonywał wszystkie ćwiczenia z pełną starannością.

Po 12 tygodniach terapii u pacjenta w znaczący sposób zwiększyła się zdolność zapamiętywania coraz większej ilości materiału słownego. Mężczyzna rozwiązywał coraz trudniejsze krzyżówki, zapamiętywał dużo więcej informacji niż przed terapią, np. oglądając telewizję czy czytając gazetę. Po zakończonej terapii logopeda prowadzący pana Andrzeja stwierdził, że znacznie poprawiła się jego percepcja i skupienie podczas wykonywania ćwiczeń logopedycznych bez użycia muzyki. 


\section{Podsumowanie}

Dla pacjentów z afazją akustyczno-mnestyczną techniki kognitywne są motywacją do pracy nad procesami poznawczymi, takimi jak uwaga czy pamięć, a także do wykonywania innych operacji myślowych. Pozwalają również na polepszenie funkcjonowania językowego pacjentów, a co za tym idzie - poprawie ulega także ich jakość życia.

W stosowaniu technik kognitywnych, jak również wszystkich innych z wachlarza technik muzykoterapii neurologicznej, bardzo ważnym jest, aby odpowiednio dobrać utwory, ich parametry, harmonię, dźwięk (Paszkiewicz-Mes, 2013). Równie ważny jest staranny dobór wykonawców i instrumentów muzycznych, który powinien być uzależniony od rodzaju schorzenia, typu osobowości pacjenta, jego stanu psychicznego oraz celów terapeutycznych, które chcemy osiągnąć.

\section{Bibliografia}

BAKer, F., \& TAMPLIN, J. (2006). Music therapy methods in neuro-rehabilitation. A clinician's manual. London: Jessica Kingsley Publishers.

Bukowska, A. (2012). Muzykoterapia neurologiczna. W: K. Stachyra (red.), Modele, metody ipodejścia w muzykoterapii (s. 165-178). Lublin: Wydaw. Uniwersytetu Marii Curie-Skłodowskiej.

GalińsKa, E. (2015). Znaczenie muzykoterapii w rehabilitacji neurologicznej. Psychiatria Polska, $49(4), 835-846$.

Herzyk, A. (1997). Taksonomia afazji. Kryteria klasyfikacji i rodzaje zespołów zaburzeń. Audiofonologia, X, 83-101.

Kinalski, R. (2008). Neurofizjologia kliniczna dla neurorehabilitacji. Podręcznik dla studentów i absolwentów wydziałów fizjoterapii. Wrocław: MedPharm.

ŁURIA, A.R. (1976). Problemy neuropsychologii i neurolingwistyki. Warszawa: PWN.

Maruszewski, M. (1966). Afazja. Zagadnienia teorii i terapii. Warszawa: PWN.

PANAsiuk, J. (2012a). Afazja a interakcja. Tekst, metaTekst, konTekst. Lublin: Wydaw. Uniwersytetu Marii Curie-Skłodowskiej.

Panasiuk, J. (2012b). Diagnoza logopedyczna w przebiegu chorób neurologicznych u osób dorosłych. W: E. Czaplewska, \& S. Milewski (red.), Diagnoza logopedyczna. Podręcznik akademicki (s. 263-321). Sopot: Gdańskie Wydaw. Psychologiczne.

Paszkiewicz-Mes, E. (2013). Muzykoterapia jako metoda wspomagająca leczenie. Hygeia Public Health, 48(2), 168-176.

Pąchalska, M. (1999). Afazjologia. Warszawa-Kraków: PWN.

Pąchalska, M. (2008). Patogeneza i neuropsychologiczna diagnostyka afazji. W: Ł. Domańska, \& A.R. Borkowska (red.), Podstawy neuropsychologii klinicznej (s. 153-191). Lublin: Wydaw. Uniwersytetu Marii Curie-Skłodowskiej.

RUdA, K., \& TrYpka, E. (2013). Terapeutyczne znaczenie muzyki dla regulowania zaburzeń zachowania w rehabilitacji pacjentów chorujących na otępienie. Psychogeriatria Polska, 10(4), 157-164.

STYCZeK, I. (1981). Logopedia. Warszawa: PWN. 
Thaut, M.H. (2005). Rhythm, Music, and the Brain: Scientific Foundations and Clinical Applications. New York: Routledge.

Thaut, M.H., \& Hoemberg, V. (2014). Oxford Handbook of Neurologic Music Therapy. Oxford: Oxford University Press.

Thaut, M.H., McIntosh, G.C., Hoemberg, G. (2015). Neurobiological foundations of neurologic music therapy: rhythmic entrainment and the motor system. Frontiers in Psychology, 5, 1-6. 